\title{
Bordeaux Wines: An Archetypal Terroir Cluster?
}

\author{
Marie-Claude Bélis-Bergouignan
}

\begin{abstract}
Research Group on Theoretical and Applied Economics, Université Montesquieu, Bordeaux IV, Avenue Léon Duguit, 33608 Pessac Cedex, France
\end{abstract}

\begin{abstract}
The object of the present article is to use the example of the cluster concerning Bordeaux wines to show that the opposition between the porterian brand cluster and the terroir based cluster is simplistic. We intend to reveal how the Bordeaux wine cluster, reputed for being the archetypal terroir based cluster, derives from each dimension. First, if this cluster was historically built around a strong territorial identity, this is not the only definition of the traditional Bordeaux model. Second, during the nineties, this model was subject to a lot of internal and external tension, linked in particular to its difficulties to face shifts in the international wine market. Considerable transformations have already been taken on: they combine the reassertion of the reference to terroir with the renewed dimensions of innovation and competitiveness.
\end{abstract}

Keywords: Bordeaux wines, châteaux, cluster, competitiveness, terroir.

\section{INTRODUCTION}

Those who are even only remotely involved in local industrial developments must, today, be aware of the cluster concept. Porter [1, p. 78] defines a cluster as a form of organization whose competitiveness is based on the existence of close relations between actors linked by common or complementary objectives, rooted in a given territory. Aylward [2, p. 248-249] particularly underlined the universality of the concept. It is, first of all, a privileged representation of the territory, expressing both the spontaneous modes for implementing the economic activity and the competitiveness of the places where it has been built. Secondly, it can be a public policy strategy aiming to improve the economic and competitive performance of a given economic and territorial area.

The universality of the concept collides with the diversity, observed in the territories, and which refers to the multiplicity of sector-based specializations, as well as to the specificity of both the production's local dynamics and the interactions between the players, who make up the territory. Hence the importance for procedures focusing on the analysis of the territorial dynamics as observed in specific clusters, such as the Californian wine cluster, which has been used as a privileged example in Porterian analysis [1].

The dependence of vine-growing and wine-producing clusters on its territorial resource has traditionally been emphasized as wine companies have always emerged in proximity to grape-growing regions [3]. This dependence has been formulated in terms of "site specificity", according Marshall's theory [4]. These wine clusters have been analysed, notably by Porter [1-3], in terms of geographic proximity effects [5]. Subsequently, the crisis affecting Old

*Address correspondence to this author at the Research Group on Theoretical and Applied Economics, Université Montesquieu, Bordeaux IV, Avenue Léon Duguit, 33608 Pessac Cedex, France; Tel: +(33) 5568485 53; +(33) 5568486 47; E-mails: marie-claude.bergouignan@u-bordeaux4.fr, marie-claude.bergouignan@orange.fr
World wines and the barely resistible rise in New World wines in a context of globalization [6] has provoked intense interest from both researchers and policy makers [2]. This context has marked the opportunity for distinguishing between porterian vine-growing and wine-producing clusters, oriented towards innovation and competitiveness, and terroir vine-growing and wine-producing clusters. Hence the dissociation between the traditional model, based on the Old World producers' terroir, and the model said to be "technological", based on New World producers' variety of vine. As the terroir model has its weaknesses, Old World producers, particularly French producers, should be revitalized through the inspiration they can find in the New World's best practices.

The object of the present article is to use the example of the cluster concerning Bordeaux wines to show that the opposition between the porterian cluster and the terroir based cluster is simplistic and artificial. Thus, we rely on the idea that the specificity of agrofood clusters do not lie in the intrinsic nature of the terroir but, rather, in the specific articulation of their territorial and socio-economic dimensions. In fact, we will reveal here how the Bordeaux wines cluster, reputed for being the archetypal terroir based cluster, derives from an articulation of these dimensions. First, if this cluster was historically built around a strong territorial identity, this is not its only definition. The traditional Bordeaux model, as it was defined in the seventies, and which can, in some respects, be qualified as archaïc [7], has developed immensely. During the nineties, it was subject to a lot of internal and external tension, linked in particular to its difficulties to face shifts in the international wine market. Considerable transformations have already been taken on: they combine the reassertion of the reference to terroir with the renewed dimensions of innovation and competitiveness. Beyond its empirical aspects, the Bordeaux wines case study aims to provide a contribution to the cluster theory by showing that the agroclusters' territorial dimension is not limited to geographic proximity or to "natural" characteristics. The specific articulation of terroir to the cluster's organization and strategy contributes to the 
comprehension of the coevolutive nature of the cluster's dynamics.

The present paper is structured as follows. Section 2 deals with the empirical and contextual dimensions of the research, introducing the features of the Bordeaux wines region. Section 3 focuses on the theoretical cluster framework, emphasizing its main analytical dimensions and drawing some evidence from the contribution of this framework to the analysis of wine clusters, focusing specifically on the territorial dimension. The following two sections analyze the dimensions of the Bordeaux wine cluster in the light of the principles exhibited in Section 3. Section 4 focuses on the cluster's key players' structured interactions, which may or may not be marketable, and on the transformations which they recently incurred. Section 5 is devoted to the territorial dimensions concerning the regulations by which this cluster is determined, at varying spatial scales. Finally, Section 6 is devoted to a reflection upon the future of the Bordeaux wine cluster; an issue of strategic governance trying to evolve, according to Mytelka and Farinelli [8], from a spontaneous cluster, whose regulation results mostly from the willingness of actors, to an organized cluster, characterized by a common organized development strategy.

\section{EMPIRICAL AND CONTEXTUAL DIMENSIONS OF THE RESEARCH}

Information gathered for this research was obtained through different channels. First, the paper draws on an indepth survey of literature dealing with the French wine industry, and particularly, that of Bordeaux. This literature includes the following two sources. Firstly, books dealing with the analysis of the Bordeaux wine model from an economic and historical [7-9] perspective, but also French reports dealing with the crisis and issues concerning the Bordeaux wine cluster [10]. The paper also draws on various empirical papers dealing with the same subject, some of them stemming from previous personal research, mainly focused on the analysis of strategic operations and concentration in the Bordeaux wines area $[11,12]$ and on the vine-growers' innovative behaviour, notably their environmental innovations [13].

Secondly, we have used both quantitative and interviewbased qualitative material. Quantitative data were collected between 2008 and 2009, using several sources: regional industry data collected by INSEE $^{1}$ or by the Agriculture Ministry through the Agreste ${ }^{2}$ website or data collected and presented by CIVB (Inter-professional Council for Bordeaux Wine $)^{3}$, statistics collected for their own use by professional unions of cooperatives and wine-traders. To acquire supplementary information on the main interactions and innovative attitudes, we have conducted thirty in-depth interviews in wine châteaux and with cooperative leaders and traders.

\footnotetext{
${ }^{1}$ The French organism producing official statistical information at national and regional levels (http://insee.fr).

${ }^{2}$ Agreste Aquitaine: http://oav.agreste.agriculture.gouv.fr.

${ }^{3}$ The CIVB (Conseil Interprofessionnel du Vin de Bordeaux) has existed since 1948. This organization unites three professional families: wine brokers, vine-growers and merchants (http://bordeaux.com).
}

The following elements offer contextual insight into the identity of the vine-growing and wine-producing area concerning Bordeaux wines. They comment on some of the data compiled in Table 1. Vine-growing and wine-producing activities confined to a given territory, Gironde a South-West French department, can be considered to be in character with the first dimension of a cluster, i.e. the geographical proximity, as stressed by Boschma [5], and exhibited in the following map of the cluster. Indeed, this territory is characterized by the colocation of an extended group of vine farms, so that eight out of ten farmers cultivate the vines, whose land covers nearly half the Gironde agricultural area, i.e. nearly 120000 ha. In addition, the area is highly specialized: wine businesses, which are localized in the same area and involve specific skills, benefit from a common regulatory framework and a prominent insertion in leading trade flows. These elements, which we have detailed below, reinforce the hypothesis that Bordeaux wines may be subject to a representation in terms of cluster.

First, agricultural areas dedicated to producing wine are strictly confined by the regulations of the designation, the "Appellation d'Origine Contrôlée" (AOC). The AOC defines the area of production (geographical boundaries clarified by "appellation") and selects the proportion of grape varieties which authorizes planting varieties expected to guarantee the type of wine produced and prohibits others. It also defines the minimum required percentage of alcohol, as well as the maximum yield, going hand in hand with cultural practices in line with planting density and the vineyard's methods of working. In 30 years Gironde's AOC area has increased by $81 \%$ and the average AOC yield per ha has increased by $53 \%$ while annual allocations of planting rights have resulted in the conversion from mixed farming operations, including secondarily cultivated vines, to monoculture vineyard activities ${ }^{4}$. Nowadays, vine-growing areas are essentially devoted to the production of wines having received the AOC's approval, that is to say, 95\% of still wines ${ }^{5}$ and for $89 \%$ of red wines (cf. Table $\mathbf{1}$ ).

These figures are well over the national average: the national share of farm land devoted to vines represents $3.2 \%$, whereas in Gironde it represents $48.1 \%$. The large majority of vineyards is still devoted to "conventional" practices as their environmentally-friendly practices remain individual and, for this reason, not so well identified up to now despite public labels. For instance, the Integrated Agriculture label, issued in 2002 in France, has been adopted by about a hundred of vine-growers in Bordeaux area ${ }^{6}$. As for organic viticulture, according to Syndicat des Vignerons Bio $^{7}$, the Bordeaux vineyard increased its surfaces rapidly in the last 5 years but they are still limited: it exhibits over 1,100 ha (about $1 \%$ of the Bordeaux vineyard) and about 180 vinegrowers.

By the way, the Bordeaux wine region, which ranks among vineyards with coherent viticultural identity [9], is increasing in appellations with a total of 57 . The map

\footnotetext{
${ }^{4}$ Agreste Aquitaine: http://oav.agreste.agriculture.gouv.fr.

${ }^{5}$ Still wines are those which have no carbonic mobility, as opposed to a sparkling wine.

${ }^{6}$ Source : UIPP (http://www.uipp.org/).

${ }^{7}$ Syndicat des Vignerons Bio d'Aquitaine (http://www.vigneronsbioaqui taine.org).
} 
presented above identifies, in 2009, for reasons of clarity, 36 main entities which account for these 57 AOCs.

Rules differ according to each appellation. Concerning the proportion of grape varieties, the main red vine varieties are black Merlot (62\%), Cabernet- Sauvignon (25\%), and Cabernet franc (12\%) (cf. Table 1). According to AOC, allotment between different varieties is heterogeneous: for example, there is more of the black Merlot in Saint-Émilion than in the Graves area ${ }^{8}$. Similarly, the planting density varies according to the appellation: high density $(8,000-$ 10,000 vine stock/ha) for prestigious appellations (PessacLéognan, Margaux, Saint-Julien); lower (5,000 to 6,000 vine stock/ha) for the Libourne area and regional appellations (Médoc, Graves and Côtes); very low density (2,000 vine stock/ha) in the Entre-Deux-Mers area ${ }^{9}$. Imposed yields and alcohol percentage also vary from one AOC to another and regardless of any relation established with the planting density. Consequently, it is understood that, depending on the appellation, the same authorized level of yield per hectare gives very different qualitative results.

In terms of turnover, the Bordeaux wines area represented, in 2007 (cf. Table 1), the $1^{\text {st }}$ vineyard in France in AOC volumes, the $1^{\text {st }} \mathrm{AOC}$ vineyard exporting still wines (32\% of French exports in still wines); domestic sales represented $67 \%$ of turnover. The Gironde region owes a lot to vine-growing and wine-producing regarding economic performances: 10,000 harvest declarants, 400 merchants marketing $75 \%$ of production, 100 wine brokers, 44 cooperatives and 4 cooperative unions, 56,000 direct and indirect jobs.

The quality of grapes is the result of the interaction of 4 factors: the site, the climate, the type of soil and the proportion of grape varieties. There are two sides to the topography of the Gironde: to the west, a plateau going down to the Atlantic coast; to the east, a sinuous and hilly, low plateau. Bordeaux enjoys a mild, oceanic climate and has a range of soils particularly favourable to growing vines: gravel, composed of cobbles and sand, which filters easily and has calorific properties which encourage grape maturation; soils which are essentially argilo-calcareous of a moist character. Irrigated by two large rivers, the Garonne and the Dordogne, as well as by numerous streams, Bordeaux's vineyard has the advantage of hydric conditions which are favourable to quality wine growing. It is the interaction of both climate and site that form several localized climates. A microclimate, depending on the nature of the soil, defines an environment known as a terroir, which is a complex notion for further thought (Section 5).

To be satisfied with this presentation implies accepting only a limited view. The previous paragraphs aimed at describing the main features of Bordeaux wines in terms of geographical or pedoclimatic characteristics and of the critical mass of vine and wine activities. As shown in the next paragraph, this description has introduced the hypothesis of a cluster, but falls short of esteeming the Bordeaux wine region as a cluster. The analysis now needs to be clarified by exhibiting a specific framework so as to go beyond this first step.

\footnotetext{
${ }^{8}$ Source: CIVB (http://bordeaux.com).

${ }^{9}$ Source: CIVB (http://bordeaux.com).
}

\section{WHICH THEORETICAL CLUSTER FRAME- WORK?}

\subsection{A Fruitful Concept for Analyzing the Systems for Local Food Production}

Porter has contributed to placing clusters at the heart of institutional and economic debates, by giving a sense to the paradox of globalized economies having to put their competitiveness on a local scale to the forefront of their concerns. However, if this analysis has proved that there are advantages, some authors have ticked off excessive use of the "catch-all" concept [14]. Others have assessed the applicability of the cluster for the analysis of industrial sectors, but denied the use of this model to analyze agrofood sectors.

Individual critics have focused specifically on the local dimension, but with conflicting assessments. First, this concept raised some difficulties in the agrofood sectors, especially in the developping countries, as some researchers rejected Porter's definition as it did not accentuate enough the territorial dimension [15]. However if the strict "geographical and sectoral" definition satisfied some researchers, others, on the contrary, have been known to protest against underlying presuppositions putting geographical proximity at an advantage [5-16]. If territory is the key concept which inspires all the regional public policies, it is not by leaning exclusively on agglomerations of activities that economic growth and competitiveness will generate. In reality, knowledge creation and innovation are fundamental in regards to the development of clusters. Hence, the focus on analysing the links between capacity for learning $[16,17]$ and territorial anchoring ${ }^{10}$. If the "spatially bounded" character of knowledge flows has been highlighted, it appears that the nature and intensity of the interactions are not only associated with the geographical proximity.

In turn, by stressing more on the globalization process, some researchers focused on the domination and, consequently, the deletion of territories. For example, Hendrickson and Heffernan [19] studied the rise of global food chain clusters and their extension into food retailing. From this globalization process, one might have concluded that local food clusters could lose all possibility of control over the decision process. Instead, these authors show that global food systems are vulnerable, as they are increasingly unstable. From this attribute, they infer the existence of windows of opportunity for territories, on the side of consumers and/or producers. This argument contributes to supporting the hypothesis of the diversity of viable strategies for agrofood players in the territories. It also induces the inclusion of more collective, organizational and regulatory, issues.

Therefore, the organizational structure [20] which governs interactions between companies, training and research centres, and regulatory authorities has to be taken into account, given that these may be local or outsourced interactions. Following Rychen and Zimmermann [21] "on the one hand, territories can

\footnotetext{
${ }^{10}$ The foundations of territorial anchoring, as regards technological and industrial activities, lie in the conjunction between the aspects of organizational proximity, indicating the intra-firm or inter-firm industrial dimension, and the aspects of geographical proximity, on which the territorial dimension is founded [18].
} 
Table 1. Bordeaux Vine-Growing and Wine-Making Cluster Identity Card for 2007

\begin{tabular}{|c|c|c|c|}
\hline \multicolumn{2}{|c|}{$\begin{array}{l}\text { Areas } \\
\text { Largest French AOC vineyard (ha) } \\
\text { - 2007: 120, } 215 \text { ha } \\
\text { - 2005: } 123,334 \text { ha } \\
\text { Harvest } \\
\text { - 2007: 5,7 millions hl (2005: } 6 \text { millions hl) } \\
\text { Red: } 89 \% \text {, white: } \mathbf{1 1 \%} \\
\text { Bordeaux represents } 2.3 \% \text { of world wine production }\end{array}$} & \multicolumn{2}{|c|}{$\begin{array}{l}\text { Players } \\
57 \text { appellations grouped within } 28 \text { Management Organisms (ODG) remplacing } \\
57 \text { viticultural unions } \\
\text { - } 10,000 \text { harvest declarants } \\
\text { - } 400 \text { merchants marketing } 75 \% \text { of production } \\
\text { - } 100 \text { brokers } \\
\text { - } 44 \text { cooperatives and } 4 \text { cooperative unions } \\
\text { - } 56,000 \text { direct and indirect jobs }\end{array}$} \\
\hline \multirow{2}{*}{\multicolumn{2}{|c|}{$\begin{array}{l}\text { AOC groups (total vineyard area \%) } \\
\text { Bordeaux and Bordeaux Supérieur: } 46.1 \% \\
\text { Médoc and Graves: } 16.7 \% \\
\text { Saint-Émilion / Pomerol / Fronsac: } 10.2 \% \\
\text { Red Côtes: } 14.4 \% \\
\text { Dry white: } 7.6 \% \\
\text { Sweet white: } 3.2 \%\end{array}$}} & \multicolumn{2}{|l|}{ Vine varieties in area \% } \\
\hline & & $\begin{array}{l}\text { red: } \\
\text { Merlot }(62 \%) \\
\text { Cabernet Sauvignon }(25 \%) \\
\text { Cabernet Franc }(12 \%) \\
\text { Secondary varieties: } \\
\text { Cot (or Malbec), Petit Verdot, } \\
\text { Carmenère }(1 \%)\end{array}$ & $\begin{array}{l}\text { white: } \\
\text { Sémillon (54\%) } \\
\text { Sauvignon blanc (36.5\%) } \\
\text { Muscadelle (6.5\%) } \\
\text { Secondary varieties: Colombard, Merlot } \\
\text { blanc, Ugni blanc (4\%) }\end{array}$ \\
\hline \multicolumn{2}{|l|}{ Development of 2007 sales } & \multirow{2}{*}{\multicolumn{2}{|c|}{$\begin{array}{l}\text { Adaptation measures of supply and demand } \\
\text { Grants for grubbing out } \\
\text { - prohibition of new plantings until } 2016 \\
\text { - replanting allowed where producers undertake to grub up equivalent areas } \\
\text { planted with vines } \\
\text { Grubbing in Bordeaux area } \\
2007: 1,000 \mathrm{ha}(2006: 1,200 \mathrm{ha}) \\
\text { Strongly restrained voluntary and assisted distillation } \\
\text {-2006: } 368,000 \mathrm{hl} \text { of wine }\end{array}$}} \\
\hline $\begin{array}{l}\text { Pomerol, Saint-Émilion, } \\
\text { Fronsac: }+3 \% \\
\text { Médoc, Graves: }+2 \% \\
\text { Côtes Bordeaux: - } 4 \% \\
\text { Bordeaux Red: }-6 \%\end{array}$ & $\begin{array}{l}\text { Bordeaux Supérieur: }-5 \% \\
\text { Bordeaux White: }+2 \% \\
\text { Bordeaux markedly sweet (Moelleux): } \\
+7 \% \\
\text { Bordeaux luxurious dessert } \\
\text { (Liquoreux): }+2 \%\end{array}$ & & \\
\hline \multicolumn{2}{|c|}{$\begin{array}{l}\text { Turnover: } 3.4 \text { thousand million } € \\
\cdot 1^{\text {st }} \text { French vineyard in AOC volumes } \\
\cdot 1^{\text {st }} \text { AOC still wine exporting vineyard } \\
\cdot 1^{\text {st }} \text { place for home consumption } \\
\text { Sales in France: } 67 \% \text { of turnover } \\
\cdot 1 \text { st place in supermarket sector ( } 43 \% \text { of home sales) } \\
\cdot 15 \% \text { in hard discount } \\
\cdot 42 \% \text { to other circuits (direct selling, restaurants, wineries etc.) }\end{array}$} & \multicolumn{2}{|c|}{$\begin{array}{l}\text { Exports in 2007: } 1.94 \text { million hl }(+\mathbf{7} \%) \text { for turnover } \mathbf{1 . 3 9} \text { thousand million } \\
\mathbf{E}(+\mathbf{9 \%}) \\
\text { Export sales } 33 \% \text { of turnover }=32 \% \text { of French exports in still wines }(29 \% \text { in } \\
2005) \\
\text { Proportions: } \\
-\mathbf{6 3 \%} \text { to } \mathbf{E U} ; \mathbf{3 7 \%} \text { to non } \mathbf{E U} \text { countries } \\
-\mathbf{8 5 \%} \text { in red wines ( } 6 \% \text { in volume); } \mathbf{1 5 \%} \text { in white wines }\left({ }^{\circ}+8 \% \text { in volume). }\right.\end{array}$} \\
\hline \multirow{2}{*}{\multicolumn{2}{|c|}{$\begin{array}{l}\text { Affordable Bordeaux: } \\
\text { - } \quad \text { eligible wines already imported to a given country; } \\
\text { - } \quad \text { situated in a consumer accessible price bracket ( } 4 \text { to } 15 € \text { ). } \\
\text { - } \quad \text { wines registered blind tasted by a panel of local experts, } \\
\text { acknowledged professionals (sommeliers, journalists, etc). } \\
\text { A selection of } 50 \text { to } 100 \text { wines having obtained the best marks is } \\
\text { accepted. Each selection is the subject of a booklet (downloadable } \\
\text { version from CIVB site: bordeaux.com) }\end{array}$}} & \multicolumn{2}{|c|}{ Top-ten of Bordeaux brands ( 000 cases) } \\
\hline & & $\begin{array}{l}\text { Mouton-Cadet (Baronnie): } \\
\text { 1,100 } \\
\text { Malesan (Castel): 1,050 } \\
\text { Baron de Lestac (Castel): } 750 \\
\text { Cellier Yvecourt (Yvon } \\
\text { Mau): } 375 \\
\text { Ginestet (Ginestet): } 250\end{array}$ & $\begin{array}{l}\text { Dourthe } \mathrm{n}^{\circ} 1 \text { (CVBG): } 150 \\
\text { Marquis de Chasse (Ginestet): } 125 \\
\text { Premius Exigence (Yvon Mau): } 75 \\
\text { Calvet Réserve (BVC): } 85 \\
\text { Sirius (Sichel): } 80\end{array}$ \\
\hline
\end{tabular}

Source: author from CIVB (bordeaux.com), Agreste data (http://agreste.agriculture.gouv.fr.), Wine Business International, October $9^{\text {th }}$ 2006 (www.wine-businessinternational.com/wbi_1_2006france.pdf).

no longer be considered as closed systems, and the questions of internal and external coordination cannot be regarded separately. On the other hand, coordination does not require durable colocation: many regular interactions between partners are satisfactorily achieved in spite of wide geographical separation." This calls for a reconsideration of the territorial dimensions of wine clusters.

\subsection{Vine-Growing and Wine-Producing Clusters: Terroirs Versus Vine Varietal?}

Taking the example of the New World vineyards-either Australian [22] or South African [23]—some analyses shelve the territorial dimension contained in the Porterian vision, preferring to glorify the competitiveness and innovation of these clusters. Aylward [22] thereby shows the impact of the concentration involved in government encouraged productive structures, as well as in the incitation to export, backed up by a structured marketing and mass marketing policy, and in the support concerning $\mathrm{R} \& \mathrm{D}$ and innovation for developing a competitive cluster. Similarly, with regards to the South African viticultural cluster, Ewert [23] underlines the advantages of deregulation and internationalization. The Cape wine performance is remarkable considering that this industry has had to face a 
'shock to the system' in terms of local industry deregulation, increasing integration into international markets and South African legislative changes. However, he assesses that these mutations have had complex effects. On the one hand, the industry has incurred an impressive expansion and a sustained rise of exports. On the other hand, many smaller cooperative wineries now find it difficult to survive in this deregulated environment, as they are locked in a mass production trajectory which they find difficult to abandon. This situation calls for new institutions, regulations and habits, which the government is trying to set to assist them through the transformation. These two examples demonstrate the idea that "the cluster model neo-liberal development based on international integration has to be tempered" by at least two remarks: in any event, a strong impulse of public help is needed, and secondly, new rules are required as "deregulation and internationalisation have created a situation of 'winners' and 'losers", [23].

Similarly, further research has focused on Old World wines, praising its territorial aspects. Nevertheless, the territory has been and still is a central element in the organization of the world's wine industry and the corner stone of the marketing strategies of the field's players. Conversely, the term, anti-terroir would define the future strategy of the vine-growing and wine-producing world [24, p. 77]. A particularly good illustration of the latter would be specific plantation practices adopted in Chile. Some Chilean clusters have effectively set up a model for selecting plantation areas according to the desired vine and, thereby, optimized the vineyard layout in vine varietal which is well integrated in international markets.

The territory's specific advantages would therefore be easily comparable with those of a territorial rent, a fungible monopoly rent. In opposition, a-territorial clusters would bring an innovation rent, particularly via the implementation of disruptive innovation [25]. For example, the emergence of New World wines on the global market, within a market dominated by wines judged to be more sophisticated, and sometimes more expensive, would represent such a type of innovation. It would amount to the following outline: these countries first understood how to exploit new consumers' preferences for a simpler and more reasonably priced product; then, having attacked the low end of the global market, they advanced to the upper segments, compelling traditional producers to flee to the highest segments, where the market share is tightening.

Yet Overton and Heitger [26, p. 441] have pointed out that some New World wines also "have begun to see value in using regional descriptors for their wine and in promoting certain regions as having special qualities". So, New Zealand winemakers now refer to terroir, exhibiting a sort of hybridisation between New and Old World principles. The chosen example reveals much about "the way land and places are valued, revalued and promoted" not only through economic forces but also via regulatory protection and terroir narratives. Thus, the terroir, deriving from the status of a generic asset, may now be seen as a specific asset $[27, \text { p. 561 }]^{11}$, not only subsuming competencies and

\footnotetext{
${ }^{11}$ The specificity is not intended here in the sense of constraint, as is sometimes the case, as it represents an advantage.
}

knowledge aspects but also symbolizing a common territorial identity and transforming the perception of the place in the public mind [26, p. 448]. Further, the simplistic character of the terroir/vine varietal opposition may be outdated if we return to a cluster analysis taking into account the players' interactions, and their dynamics. In the emergence and development of vine-growing and wineproducing clusters, Giuliani [28-30] highlights the role of learning and of interaction within internal and external networks. "Using evidence from two Chile and Italy clusters, she finds that firms' internal knowledge bases and their external openness are more significant than intra-cluster embeddedness in explaining innovation" [29]. In the end, a cluster's viability owes as much to knowledge linkages and collective learning devices [30] and to local-global interconnections [31] as it does to market interactions between players.

Our analytical framework will be, finally, enriched considering another dimension, based on Mytelka and Farinelli's framework [8]. Their analysis highlights some critical points about the distinction between a spontaneous cluster and an organized cluster. They particularly show that the organized cluster is characterized by the following dimensions: a larger spatial scale, the presence of predetermined, often administrative or regulatory, boundaries; the emphasis on R\&T dimensions; a regulation resulting more from a common development strategy than from the willingness of actors. These elements enable us to highlight some of the actual features of the Bordeaux wine cluster.

Synthesizing all these different results has confirmed that a wine cluster is at first characterized by the colocation of its activities - i. e. their geographical agglomeration-, which induces its boundaries and partly determines its territorial anchoring. However, the territorial dimension appears to be shaped by a "complex and over-lapping series of economic, political and social processes" [26, p. 449]. These cultural and symbolic dimensions have to be articulated to the cluster's distinctive interactions. At first, the cluster is a complex system of sectoral and cross-sectoral networks of dissimilar and complementary firms, specialised around a specific link or a particular knowledge-base in a structured value chain including suppliers and consumers, but also universities, research laboratories, bridging institutions, within a competitive context (markets and competitors) (Section 4). Moreover, wine clusters must be characterized by the coevolution of this complex system with its cultural, symbolic and regulatory features at varying spatial scales, among which the terroir is a distinctive dimension (Section 5). In the most recent period, we finally see that the difficulties encountered by the Bordeaux cluster facing globalization have led to opt for a strategic attempt leading from a spontaneous cluster to an organized cluster [8] (Section 6).

\section{THE BORDEAUX CLUSTER: A SUSTAINABLE NETWORK OF LOCALIZED INTERACTIONS LINKING KEY ACTORS}

This section aims to analyze how the localized interactions between players constitute a system: i.e. a set of structured interactions that configure this system, each of the 
players taking on specific, but also scalable, functions. Fig. (1), below, brings to light the stylized features which constitute what is called the "Bordeaux model", as it has gradually formed.

Players who make up the core of the cluster are found at the centre of the ellipsis. Main organizations with whom these players are in constant interaction, and which configure the Bordeaux wines cluster, are represented on the periphery.

\subsection{The Key Players Structuring the Core Value Chain}

Upstream, the productive system is organized by the product and market interactions of three types of players: independent vine-growers, vine-growing traders and cooperative vine-growers ${ }^{12}$.

Independent vine-growers, of which there are around 5,000 today, produce grapes over approximately $70 \%$ of viticultural area. These growers make their wines (about $71 \%$ of production) on the estate, producing an average of 800 million bottles every year. Only a small part of their production (16\%), albeit rapidly growing over recent years, is subject to direct selling.

Vine-growing traders represent the second category of vine-growers, which is considered marginal, yet increasing. Large wine trading companies have recently acquired around 6,000 ha (5\% of viticultural area) either directly or in tenant farming, destined to produce their own wine, representing about $4 \%$ of volumes.

Cooperative vine-growers, of which there are 4,900 members for 44 cooperatives, producing $25 \%$ of the volume of wines produced, $98 \%$ in AOC, over roughly $25 \%$ of viticultural area. More than seven out of ten are individual vineyards, which are generally small-sized. Furthermore, almost nine out of ten are known as "exclusive", making their wine from their entire grape harvest in a cooperative winery, where wine-making and assembly as well as packaging and sales services are ensured for their member vine-growers, particularly via Cooperative Unions (4 in 2007).

Cooperative members and independent vine-growers have almost all the productive area, but it is the merchants who ensure marketing $70 \%$ of the volume of wine. There are, therefore, three types of participants involved in the process: independent vine-growers, cooperative wineries and traders. The bonds which unite these companies are mainly based on relations concerning trade in raw materials (grapes) and the finished product (wine). Vine-growers can either sell their wine directly to consumers or supply grapes to cooperative wineries or wine merchants. Then again, they may choose to produce their own wine to sell, in bulk or bottled, either to wine merchants or brokers. The latter are important intermediaries between wine-making and the business of selling.

Gironde can count around 400 merchants, who market 70 $\%$ of the production of Bordeaux wines in more than 160 countries. It is a very dense sector where the first 44 companies make $80 \%$ of the trade's turnover. From the small

${ }^{12}$ The following data are from the CIVB web site
(http://www.bordeaux.com).

family company to the multinational, the wine business offers a broad range of situations.

These merchants sell either private owner wines or brands. In the second case, the wine bought from a vinegrower or a cooperative winery is kept in merchant warehouses to continue the different phases. Wine businesses have an important regulating role, regarding markets, as their storing capacities enable them to palliate, at least partially, price fluctuation. Thus, for a long period, these players were seen as the heart of the system, because the flows circulate through the trader's decisive boost.

The broker (there are around one hundred today) has an intermediary presence which is historic in Bordeaux. The first wine merchants to come to Bordeaux were mainly foreign; the language barrier and the fact that they did not know the field brought about the profession of wine broker. The broker's role consists essentially in bringing the merchant closer to the vine-grower, in establishing an agreement between the parties and in reporting to them. The brokers also draw up official wine listings, taking into account the transactions carried out on the Bordeaux market.

Downstream in the wine value chain are the distributors who market the Bordeaux wines. In 2007 (cf. Table 1), 5.7 million $\mathrm{hl}$ were sold for a turnover of 3.4 thousand million $€$. Home sales represent $67 \%$ of the sold volume: 3.76 million $\mathrm{hl}$, for 2.01 thousand million $€$, and exports, 33\%: 1.94 million hectolitres, for a turnover of 1.39 thousand million $€$. Hypermarkets and supermarkets represent $43 \%$ of home sales: 1.61 million $\mathrm{hl}$ for a turnover of 907 million $€$. Harddiscount stores represent around $15 \%$ of the volumes of these home sales, which leaves 26\% to HORECAs (Hotels, Restaurants and Cafes) after roughly $16 \%$ have been taken into account for direct selling (from the estate, by mail order and in trade fairs).

Ultimately, the local agglomeration of these actors, and the structured interactions from upstream to downstream, determine the central structure of the Bordeaux wines cluster. The consistency and sustainability of this configuration resulted in pecuniary and technological offsets, because of the density of local production processes. We shall see below that the processes of resource creation are reinforced by a set of relationships with peripheral organizations.

\subsection{Interactions with Peripheral Organizations Broaden the Cluster's Boundaries}

Several types of players involved in the wine local productive dynamics can be found outside the central value chain, with whom they interact: suppliers, regulatory and representative organizations, technological and scientific resources, and players influencing conditions of the market. These interactions define a network which broadens the boundaries of the cluster beyond the central players. The interactions with these various peripheral organizations contribute to the overall efficiency of the whole system through the complementarities built around the wine product. It is worth signalling that these relationships go beyond the strict framework of localized relations, which is consistent with Giuliani's analysis of wine clusters [29]. 


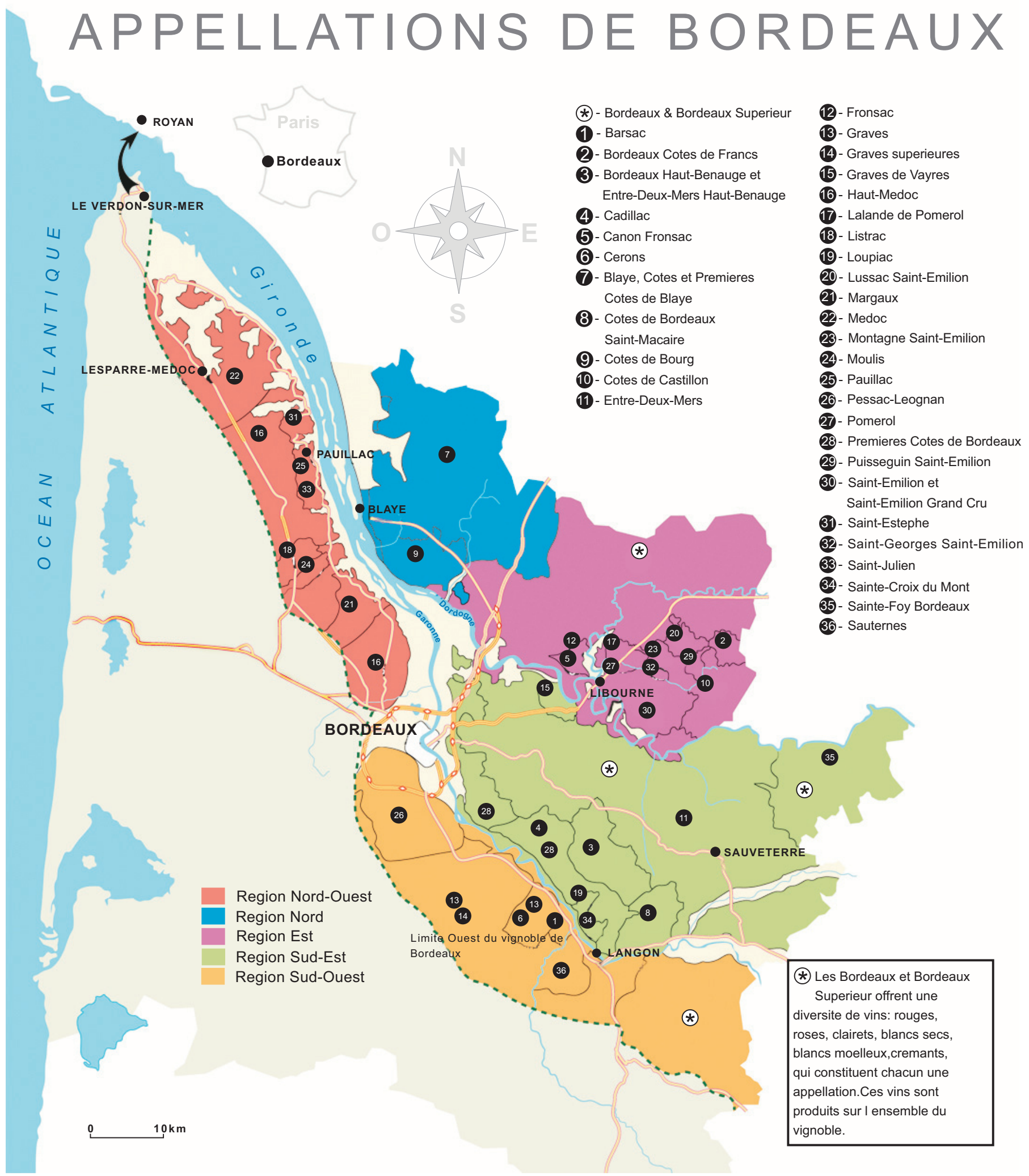

Map 1. The Bordeaux wines AOCs (Photographic credit: CIVB). Source: CIVB (http://bordeaux.com/Data/media/CarteVignoble2009_ PDF). 


\subsubsection{Relationships with Suppliers}

The presence of specialized suppliers is a factor of the cluster's performance. There is mutual dependence between suppliers and players on the field. These suppliers represent a broad range of supplementary activities: seeds, fertilizer, pesticides, cultivation material, casks, bottles and corks, to mention only the main ones. In the case of Bordeaux wines, some of the suppliers have their head office located near their market: vat manufacturers, vine and wine consultants, bottlers [13]. Whereas agrochemistry (seed, fertilizer and pesticide suppliers) is represented by multinational firms (Syngenta, Bayer Crop Science, etc), as they have only delocalized their distribution and consultancy activities to Gironde. The suppliers' role is not only to sell material and products, they also advise their local customers (cf. dotted line arrows showing circulation of knowledge in Fig. 1).

\subsubsection{Relationships with Regulatory Institutions}

Since the end of the First World War, regulations concerning the French wine-producing sector, especially that of Bordeaux, have been based on the following multi-layered statutory regulations: local, national and European. These regulations, which have, for a long time, played the role of focusing device for the local players, have led to a labyrinth of the methods of representing Bordeaux wines [32].

AOC regulations were entrusted in 1935 to a public establishment, INAO (National Institute for AOC). The INAO grants the approval to each AOC after analytical and organoleptic tests, and defines its area of production (see above). As the AOC is a collective body, the vine-growers must manifest their firm involvement. Up to now, the AOC viticultural union, which unites all the vine-growers of each AOC, collaborates with the INAO to promulgate the texts which will recognize the "appellation", define the features of the product, production conditions and methods for controlling the elaboration process.

The CIVB (see above), a leading interprofesional organization uniting brokers, vine-growers and merchants, ensures three missions; first, to improve the quality of Bordeaux wines, secondly, to ensure its world-wide notoriety and, thirdly, to support advertising, press and public relations, as well as promotion in sales outlets. Cooperatives are formed within the Aquitaine Federation for Cooperative Wineries (FCVA), which represents an organization for protection, promotion and information, although it has no marketing mission.

The AOC procedure is recognized throughout Europe, being governed by regulations relative to the Common Market Organization (Wine CMO, created in 1970), which determines the VDQPRD class (Quality Wines Produced in Determined Regions), within which AOC wines are listed, thereby differentiating themselves from table wines ${ }^{13}$.

The International Organization of Vine and Wine (OIV) is a scientifically and technically-based intergovernmental organization whose mission is to create standards aimed at developing the international wine business. The standards result in recommendations for member states, who strive

\footnotetext{
${ }^{13}$ Includes 'vins de pays', whose geographical origin is recognized, and actual table wines.
}

together to preserve the interests of both producers and consumers. Despite their overlapping, regulatory devices have played and play an undeniable role in structuring the cluster whether obtaining the collective information at lower cost or accessing to administrative and physical resources. These devices have helped to focus the attention of players and to stabilize their environment, which has enabled the development of the Bordeaux wines cluster during the 20th century [7]. However, we will show that recent transformations of these devices represent a destabilizing factor, both involving innovation incentives but also threats for the most fragile players.

\subsubsection{Interactions with Localized Scientific and Technological Resources}

In the wine sector, the R\&D process is carried out through local organizations: technical institutes, such as ITV (Institut des Techniques du Vin), representatives of producers (Chambers of Agriculture) and private firms. Basic research is done by local public research organizations, universities, and engineering schools, providing knowledge accessible to all. By using research results, firms or agricultural development centers are able to develop technological and organizational solutions, which they transmit to operators to ensure competitive wine production.

The research topics are diversified: improving vine quality, oenology, vine quality and health, economics and management. Professionnels found in Bordeaux, like Denis Dubourdieu and Michel Rolland, have been respected, worshiped and criticised. Their reputation goes far beyond cluster borders, and wineries across the world have had the benefit of their oenological knowledge. The last decade has seen the creation in Bordeaux of the Institute of Vine and Wine Sciences (ISVV), gathering the whole $R \& D$ and training potential of the cluster. Research results are distributed in several forms, either directly to users, during training courses, through participating in policy forums of various organizations, meetings (conferences, technical publications, etc.), and trade shows, such as VINEXPO ${ }^{14}$ or VINITECH. French state and local authorities funding of shared cognitive resources, despite the actor's unequal access within the cluster, undoubtedly promote technology transfer and learning through the activation of formal and informal networks.

\subsubsection{The Local Response to Global Market Conditions}

It is now widely-known that judgments from prescribers-especially the US wine expert Robert Parker, for Bordeaux wines-are cognitive cues for a large number of players in the world of wine, whether producers or consumers. In Bordeaux, the so-called wine parkerisation, stemming from Parker's testing device, first intended to serve as a guide for consumers, has undoubtedly led us back to recommendations concerning the practices of certain producers.

\footnotetext{
${ }^{14}$ Created in 1981, VINEXPO Bordeaux is held every two years. It now represents the worldwide meeting-place for large business operators in the trade of wines and spirits. Created in 1977, VINITECH is the reference for professionals of the wine industry from the world over, through an international exhibition of equipment and services for viticulture and oenology, seminars and conferences, which make it the international crossroads of knowledge and expertise.
} 


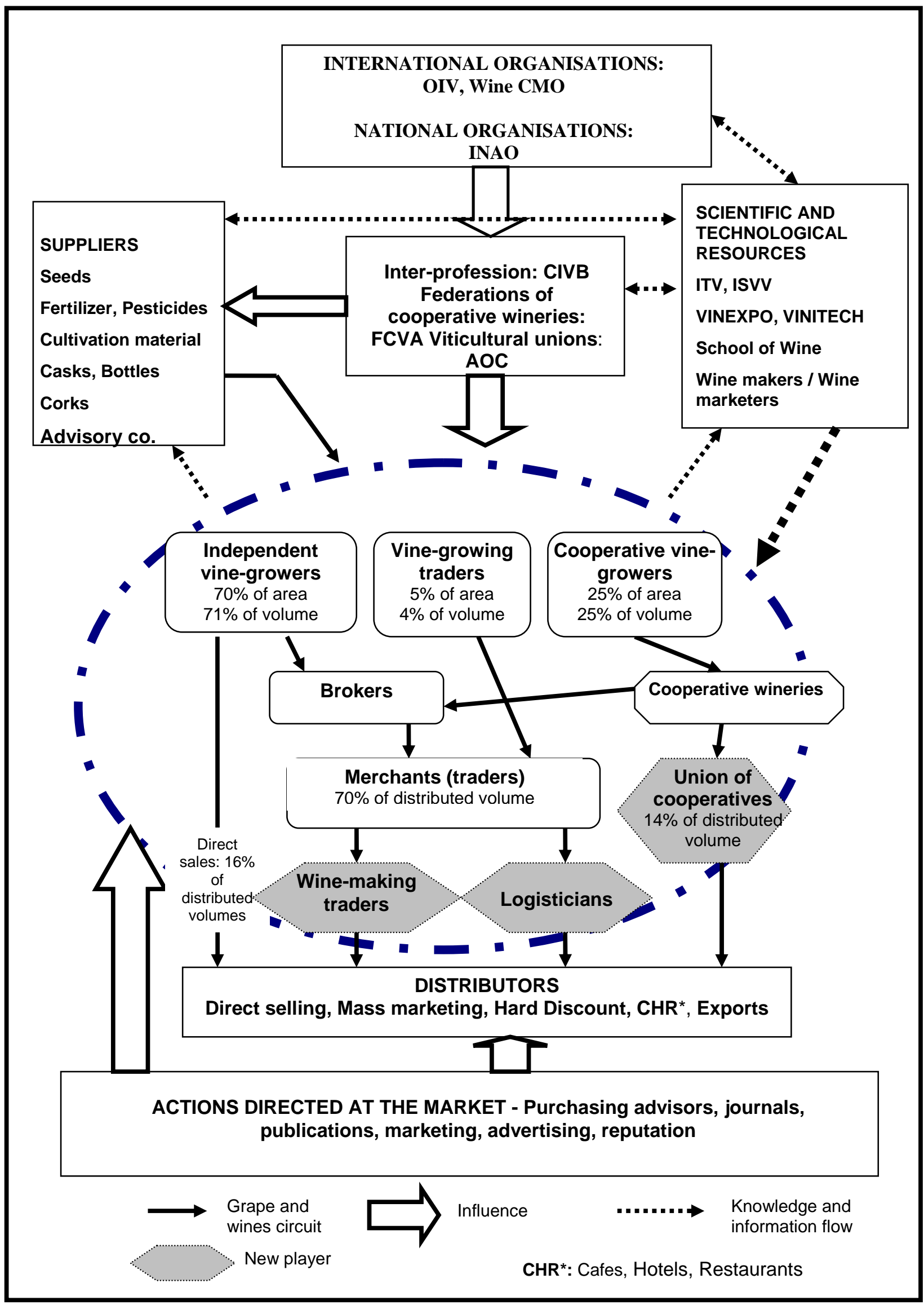

Fig. (1). Bordeaux wines cluster (source [7] modified and adapted by the author). 
Marketing being among its main missions, the CIVB, which turns to be the dominant organism of the whole system, has implemented marketing efforts aimed at maintaining and developing an economic environment conducive to the wines of Bordeaux. These efforts consist in promotion, advertising, public relations, the press and training conducted by Bordeaux's Ecole du Vin. Sales force coaching is carried out in collaboration with instructors from the Ecole $d u$ Vin, for which 15,000 professionals were trained in 2007. Training these prescribers has intensified the operation known as "Affordable Bordeaux" (see Table 1); an operation aimed at both professionals and the general public, highlighting the modernity and accessibility of Bordeaux wines. Once the wines have been selected, journalists and representatives from the targeted importing country (buyers, importers, wholesalers, wine merchants, and restaurateurs) are invited to a promotional event. Since their inception in 2005, "Affordable Bordeaux" have been twice round the world, in capital cities, including Tokyo, London, Shanghai, New York, Paris and Berlin. Thus, the implementation of marketing or promotion of wine product, including the interprofesional initiatives, contributes to the reputation of the place and to the formation of a collective market power, thus strengthening the cluster's competitiveness.

We shall see below that these stylized features are partially undermined by recent changes.

\subsection{A Cluster Incurring a Transformation Process}

Following the shock of the crisis of the years 2002-2005, but also because of gradual changes over the nineties, very sensitive transformations have modified the existing interactions within the wine value chain. These transformations in the implementation of short-term actions, aimed at slowing down the effects of the crisis, have brought about the appearance of new players characterized by new skills and new interactions through a concentration and financialization process. These transformations testify both changes in the roles and influences inside the cluster, and the actor's strategic reorientations, notably from supply-pushed towards market-pulled strategies.

\subsubsection{Implementing Short-Term Coordinated Actions}

In the Bordeaux area, the wine difficulties have resulted in excess production on all markets. This oversupply has led almost mechanically to poor sales, rising inventories and falling prices. Thus, on their own side, growers have registered sale and cash difficulties while the professional and interprofesional bodies noted also lower bids from brokers. The answers given by the local regulatory bodies, including CIVB, have been oriented both downstream and upstream the value chain.

Downstream, CIVB marketing efforts mainly seek to maintain and develop a conducive environment to the Bordeaux wines. The strategy has focused the prestige 'château' as the driver of a collective 'Bordeaux image', benefiting also trademarks. Towards French consumers, marketing has promoted slogans conveying the concepts of accessibility, diversity and friendliness. Abroad, European traditional markets have been targeted, but also emerging or high potential markets, like Asia, North America and Russia. Vis-à-vis the European market, the idea was to "humorously capitalize on the word 'château' focusing on desire and seduction ${ }^{15, "}$ Towards other foreign unaccustomed consumers, the purpose was to enhance the Bordeaux wines friendliness and modernity, while suggesting different consumption modes, especially between meals.

In addition, the CIVB has promoted Bordeaux wines in an adding value price range towards key national accounts and major international and regional wholesalers. Finally, in qualitative terms, the interprofesion developed a downstream quality monitoring method, governed by an interprofessional agreement and signed by the three categories of players: wine producers, traders and brokers.

Upstream, the Bordeaux region has proceeded to establish a vine grubbing up program that led to the removal of 1,200 ha in 2006 and 1,000 ha in 2007 (see Table 1), a measure that is now generalized through the EU granting aid to producers who leave the sector after grubbing up vines. In a complementary way, "crisis distillation" of $185,600 \mathrm{hl}$ in 2005 and 368,000 hl in 2006 (see Table 1) was implemented, strategy which is now limited. Accordingly, this strategy has allowed the absorption of available stocks and a subsequent resumption of sales.

But such support did not prevent the degradation of the generic red AOC Bordeaux. These AOCs low priced wines saw their average price fall from $100 € /$ hectolitre in 2005 to $70 €$ in 2006 . Their current net outcome per hectare, either for bulk or for cooperative wines, has been falling to almost zero, thus excluding any possible remuneration for vinegrowers work. This demonstrates, for the generic Bordeaux wines, the limits of an inversion of sales decrease strategy based on lower prices.

\subsubsection{New Players Intercalated Between Production and Distribution}

Cooperatives are equipped with specific business structures, aimed to enhance their production, independently, in the form of Cooperative Unions (see Fig. 1) or by resorting to mergers $[11,12]$. There are four cooperative business entities: Alliance Bordeaux, Prodiffu, Producta and Univitis. They market the wine using their own brand, which enables a much more offensive strategy on both the home market and in exports. At the same time, they give vine growers advice in technical matters and quality improvements, a strategy which aims at boosting their range of products.

Secondly, wine merchants have occasionally been known to get together [7] when identifying with a growing control in the value chain and by developing specific wineproducing sites. This orientation, implemented in 1967 by Sichel, then by Baron Philippe de Rothschild S.A. in 1991 (in Saint-Laurent-du-Médoc), has mainly developed since 2000 , the wine producing potential of each site increasing over the years: Malromé in 1999, Dulong in 2001 (associating with Caves de Landiras in the Grands Chais de France group), CVBG (Dourthe-Kressmann) in 2002, Baron Philippe de Rothschild S.A. in 2004 (in St-André-du-Bois) and SOVEX in 2004 in Ludon. Despite these more offensive strategies, the merchants business remains quite weak for the moment. It is trapped between vine-growing, which is prone

\footnotetext{
${ }^{15}$ CIVB (http://www.bordeaux.com).
} 
to erratic variations concerning bulk wine prices, and the difficulty of setting up grapes supply contracts to enable their stabilization, following the example of the Champagne experience.

Logisticians, who are developing rapidly, also present a sensible change, downstream the value chain. Their emergence is related to the awareness of administrative or reglementary (sanitary or environmental) questions, which are more and more difficult to handle, accompanied by the complexification of the markets. These facts are pushing for a professionalization of logistics and are favorable to its providers: professionals from the traditional logistics (transport, platform manager...), but also from other professions like distributors etc.

In fact, logistics have taken hold of the food industryand especially that of vine-growing and wine-producinglater than most sectors of industry. In Gironde, these logisticians are locally established and companies are mainly linked to road transport, offering supplementary storage, making up parcels and packaging - which includes wine bottling, distribution and the final delivery. Indeed, concerning Bordeaux wine, logistics combine with outsourcing [7, p. 67]. Some of these new players are the result of successive merger-acquisitions of big operators, such as the three main groups, Euralog, Partenaires and Mitsiu, announcing the appearance of new professions which imply, moreover, new structuring. This notion of logistics penetrating the value chain is advantageous for vine-growers and merchants who see considerable improvement in their penetration power into international networks of wine sales. They are, through logisticians, relieved of direct material worries, thereby enabling them to focus on their core business: the definition of quality of wines and the prospection of the relevant market. At the same time, the optimal and stable preservation, ensured by logisticians, procure organoleptic as well as financial value to stored wines, while ensuring traceability.

This strategy is not, however, without danger as it might lead to upsetting upstream-downstream flow orientation. It promotes logistics from its subordinate position to a prominent role, through linking wine producers with distribution in numerous cases. The outsourcing of logistics might, indeed, as long as the logisticians have business and marketing knowledge, be a marginalization factor of the traders. It could go as far as modifying insight into the wine product through qualitative requirements, and therefore influence its conception. It could also serve as a form of disconnection regarding the territory, as, although logistics establishments have been set up close to the vineyards, they also connect directly with large motorway link-ups and road junctions.

\subsubsection{New Interactions Through a Concentration and Financialization Process}

Some French reports [10] assume that Bordeaux wines have become inadequate compared to those of the New World in terms of consumption. This simplistic view has been rapidly challenged by alternative diagnosis, drawing attention to the articulation between supply and demand side questions. The over-atomized structure of Bordeaux wine clusters has been especially targeted as one of the main causes for its difficulties in competitiveness. This is the reason why, between 1995 and 2005, cooperatives and merchants insisted on a concentration process already initiated in previous periods $[11,12]$. The wine cooperatives have therefore made further reorganizations, and particularly in distribution, to influence the market. The merging process has greatly reduced the number of cooperatives, which, in turn, have favoured mergers with other wine cooperatives localized in the same Bordeaux area. This demonstrates the influence of geographic proximity and the fact that the cooperatives are still linked to their territory. On the other hand, the new territorial organization has widened their productive and market abilities. Considering the range of concentration methods adopted by wine merchants, it would seem that acquisitions dominate, followed by mergers [12]. All merchants share the motive for adapting production and/or marketing to new demands, especially to New World types of consumption. Selling is the main argument, which, in conjunction with financial arguments, stimulates the opportunities either for taking over an estate or for marketing assets. These sales points, in favour of qualitative adaptation to meet the demand, are reinforced by drastic restrictions from recent European regulations concerning quantitative adaptations of supplying demand (cf. Table 1).

According to Réjalot's expression [7, p. 221], “a Bordeaux château is the object of desire". Numerous examples confirm the growing appetites of institutional investors for lucrative investments. International corporations have bought some of the main châteaux. FFP (Landholding Trust, run by Robert Peugeot), became the major proprietor of Château Guiraud in 2006. Concerned with preserving the future of her company, Mme de Lencquesaing, who took over a vineyard in 1978, decided to transmit her property (Château Pichon Longueville Comtesse de Lalande) to Maison de Champagne Louis Roederer (the Rouzaud family). LVMH (Moët Hennessy Louis Vuitton) invested in the Bordeaux cluster in 1996, taking control of Château Yquem (Sauternes). Clément Fayat (logistics) owns 5 châteaux: Clément Pichon (Médoc "cru bourgeois"), La Dominique (Saint-Émilion “cru classé”), la Commanderie de Mazeyres et Prieurs de la Commanderie, an AOC Pomerol and château Vieux-Fortin in Saint-Émilion. Already owner of three SaintÉmilion chateaux, La Mondiale, an insurance company, has just purchased the château of Cadet-Piola which belonged to the Jabiol family. Château Pedesclaux, 27 ha, "cru classé", in Pauillac, used to belong to the Jugla family and has been bought by Jacky Lorenzetti, founder of Foncia, a property group, who already owns château Lilian Ladouys in SaintEstèphe. Finally, "Longhai international trading Co Ltd" - a Chinese property group - has officially become the proprietor of Château Latour-Laguens, an estate within the Bordeaux Supérieur appellation.

The extent of this phenomenon has been exagerated by some observers and played down by others. Today, we have no accurate data enabling a correct estimate, particularly concerning property purchased by foreigners. According to Réjalot's estimations [7, p. 223], relying on the case review between 1975 and 2003, around 150 properties have been taken over by investors from outside the region. This figure represents approximately 5,300 ha of vines, 4,700 of which are red, including 1,700 ha in "Grands Crus Classés" (prestigious vineyards representing 36 large estates). There is 
no doubt that wine is a symbol of an attractive financial investment and a source of diversification for investors, confirmation of which we have witnessed during the recent subprime crisis. At the same time, for the last ten years we have seen, more than "the chateau rush" itself, the increasing investment in chateaux wines, via the creation of hedgefunds, such as Ascott Wine Management SA., based in the Bahamas. These investments, which are a source of diversification for investors, are part of the speculative bubble which characterizes the great wines of Bordeaux.

It is now necessary to turn to the symbolic and regulatory dimensions of châteaux and terroirs, which are constitutive of the Bordeaux wines cluster.

\section{CHÂTEAUX AND TERROIRS: A COEVOLUTION OF SYMBOLIC AND REGULATORY CONSTRUCT- IONS}

By analyzing Bordeaux wines' trajectory, it will be possible to bring to light what distinguishes Bordeaux, beyond the interactions structuring the cluster; that is to say, the château and the hierarchy of its terroirs. This distinctive feature must be related to the idea, expressed by Patchell [33], that "the estates require a strong territorial reputation and the territory needs differentiation between estates, and, usually, outstanding estates to initiate a reputation of excellence". Thus, we will see that if the today global competition has amplified this phenomenon, the construction of the collective reputation of Bordeaux wines has always been coupled with strategies of differentiation. It will also be an opportunity to moderate the abusive assimilation of these distinctive terroir signs, via the hybridisation with which the cluster was originally made up.

\subsection{Bordeaux Wines, Châteaux Wines}

There is more than one characteristic of Bordeaux vinegrowing, but undoubtedly its main characteristic is that on the strength of which the wine perfectly identifies with the estate where it was produced, to the point of being presented under the name of this estate, often gratified by the term "château" [7, p. 28]. In the Bordeaux area, as opposed to other vineyards, the wine is actually named after the estate from which it comes and not by that of a merchant or a brand name. The château's name should not be applied to vinegrowing estates if they are members of a cooperative winery nor to a business which usually bears the name of the merchant and/or the brand name.

The château is an original creation which is inseparable from Bordeaux wines' trajectory.

Vine-growing made its first appearance in Bordeaux during the first centuries of the Gallo-Roman occupation; it seems that the Bituriges had imported vine plants from the Empire, which adapted well and resisted winds and damp. Basilica was the original name of the vine, later to be known as Biturica [9, p. 37]. The reputation of the resulting wine spread across the whole Empire. Subsequently, during the Middle Ages, "Bordeaux's exorbitant privilege" was dedicated to exports [9, p. 52]. The English, who occupied Aquitaine at that time, granted Bordeaux an extraordinary exemption from paying export taxes, which led to creating the unique wine exporting port of the South West of France. A long period of inactivity followed in secondary vine-growing areas, such as Bergerac, rooted in their dependence on Bordeaux. "This business guarantee can be considered to be Gironde's actual birth certificate of quality" [9, p. 54]. Dutch, English and German businesses, set up in Bordeaux, gradually took over the wine trade and transport, thereby putting the finishing touches to the formation, later enabling subsidiairies to open abroad, and, from there, the early internationalization of Bordeaux's wine business. From this time onwards, the Bordeaux wine cluster was committed to a trajectory of quality wines, strongly internationalized by the trade.

As for "the invention of great terroirs", this is not the fruit of a decree, but one of years of patient work and experience on the part of vine-growers. The terroirs could undoubtedly be differentiated in terms of quality, right from the beginning, through the association of appreciations concerning pedoclimatic conditions and the quality taste of the wines. However, there can be no mistaking in the fact that the difference has been gradually made by the "virtuous circle of high quality vine-growing and wine-making" [9, p. 95].

The appearance of the Bordeaux "château" emanates from this quality trajectory and not from actual architectural inheritance. Admittedly, the vine-growing estates which use the name, draw their roots from former seigneuries, but bourgeois origins are also frequent [24] and, from an architectural point of view, seldom are they real châteaux. Saint-Emilion's territory was established in the XII ${ }^{\text {th }}$ century by the Duke of Aquitaine and King John "Lackland"of England; its jurisdiction rating in UNESCO's world heritage no doubt conveys the recognition of architectural value. In reality, this recognition owes a lot to a patrimonial complex associating the territory, the vine-growers and their emblematic product.

In actual fact, "the irresistible rise to power" concerning the "château" phenomenon only really started to gain importance in the $19^{\text {th }}$ century [9]. It is the result of technical developments, particularly vital strides in oenology, carried out in the cluster and through the impetus of Bordeaux wine producers [7]. These developments enabled economic and social changes to the wine making process, which was only just materializing at that time [24]. In this manner, the enormous wine cellars had one technical and economic aim, which was to manage, in quality and quantity, growing volumes of harvested fruit, at the same time housing machinery, ploughs and wine presses. The château was also a "social microcosm", founded on the private estate and no longer on the feudal domain [7], thereby associating the owners with the manager, the cellar master and the cellar workers. Finally, the château gave birth to a complex entity with an "aristocratic" aim associating a given territory, a product and its owner which the Bordeaux label would symbolize. All the ingredients for a construction ensuring the reputation and prestige of the product were now assembled.

\subsection{Multiple Ratings Creating Hierarchy: Crus Classés and $\mathrm{AOC}$}

\subsubsection{Crus Classés}

The second characteristic of the Bordeaux wine cluster is the attention given to terroir hierarchy, via classifications which are, strictly speaking, ratings for assessing and/or 
reorganizing estates or products [34]. The uniqueness of its many different ratings makes Bordeaux's territory a model.

Actually, terroir hierarchy has always existed in the world of wine, whether it concerns the Bordeaux cluster or other vine-growing areas. It is untrue to claim that these ratings were invented in Bordeaux [9, p. 49] as de facto hierarchies already existed, even going back as far as Antiquity. Nonetheless, the Bordeaux cluster was the first to attach an official classification to its wines. This is "an official procedure which grants a vineyard with a distinction and a position within a qualitative hierarchy" [7, p. 318]. Bordeaux has four ratings, depending on the sub region and type of targetted production. The oldest dates back to 1855 , and is still in force and only amendable for a 1973 "cru", concerning the Médoc, Sauternes and a Graves cru. The 1953 Graves rating was modified in 1959 and although it is contested, is now unamendable. The third concerns SaintÉmilion "crus", revisable every ten years, and the fourth concerns Médoc "crus bourgeois", also revisable every ten years [7, p. 318].

\subsubsection{Quality Institutionalized by the AOC}

As opposed to New World countries, where either the quality of the vine variety or the brand indicates the quality of wines, the French vine-growing field is composed in such a way that production strategies are structured according to whether they belong to an AOC, which, in turn, depends on the notoriety of the region in which it is located [24]. Two problems were at the root of the procedure for institutionalizing the quality of wines: a case of fraud which appeared at the end of the $19^{\text {th }}$ century and a clash between the wine trade and vine-growers at the beginning of the $20^{\text {th }}$ century.

During the second half of the $19^{\text {th }}$ century, the supply of wine was not enough to satisfy a regularly growing demand, to such an extent that winemakers resorted not only to importing wine, but also to producing ersatz wine in order to cope with the growth in mass production. This type of fraud could have been very damaging to the reputation of vineyard $^{17}$ wines on foreign markets. Stanziani [35] describes a situation of radical uncertainty which translates into the breaking of quality conventions: the standards of the period do not meet the new questions, especially because the wine industry becomes the scene of a controversy over fraud and forgery. The parliament addressed the crisis through the 1905 law, which paves the way for an institutional definition of main products, precise enough to establish the rules of the game and at the same time flexible enough to make the competition practicable.

These laws were followed by further series of measures aiming at consolidating and extending the protection of vinegrowers from the wine trade, the main trouble-maker. The outcome was to see the Gironde demarcated as an exclusive vine-growing area, excepting forest areas, in 1907. Finally,

\footnotetext{
${ }^{16} \mathrm{~A}$ "cru" is a vine-growing estate or vineyard. A "cru classé", strictly speaking, indicates an estate found in the list of "crus" distinguished by the 1855 ratings, the Graves ratings or the Saint-Emilion ratings. Broadly speaking, it refers to any vine-growing estate which has been distinguished by one of the four great rating systems.

${ }^{17}$ Sometimes a "fermented mixture of raisins, redcurrants and other ingredients" was hidden under the labels [24].
}

in 1935, a law on the AOC marked 'victory' for vinegrowers over the wine trade [36], thereby institutionalizing the quality and ensuring a privileged position for French wines on both national and international markets. AOC regulations have endured, particularly because they emanate a "restrained laisser-faire". In fact, during negotiations, where both wine producers and the state aim at determining production rules, it is the wine producers who decide on these constraints even if public regulations strongly constrain the producers' range of technical and business choices.

"Created in order to fight against fraud, the AOC is now useful in backing collective quality strategies. Forces of law and order will be called to intervene within the framework of these prerogatives, using "bimodal" regulations, which guarantee the security of the products and encourage wine producers to make efforts concerning quality. The legislator assigns agents to procedures for quality management when it is impossible to define general rules applicable to all regions and areas of production" [36]. The diversity of AOC rules can be explained by this specific mode of governance, even concerning those between production areas which make up the Bordeaux wine cluster. This diversity can sometimes be the basis for the empowerment of certain AOCs. This fact is confirmed by Patchell [33] analyzing how the diversity in integrating "collectivity and differentiation" of two Bordeaux AOCs leads to different accomplishment of "their territorial ambitions".

It therefore appears that crus classés and AOC have functioned in such a way as to form a double barrier to stop table wines and "vins de pays' ${ }^{18}$ from entering, and instigated an "appellation rent" [37] for reputed vineyards. This rent was maintained until today causing an increase in the average value of vines in the area up to $58,220 € /$ ha in $2007^{19}$. However, it mainly results of the explosion of the value of prestigious estates, like Pomerol that can be negotiated at around 900,000€/ ha.

\subsection{Hybridizing and Blurring Distinctive Signs of Quality}

\subsubsection{AOC Multiplication and Fragmentation}

Since 1935, different appellations (AOC) have met with a reduction and fragmentation phenomenon as the Bordeaux wine cluster trajectory has developed. We have already observed that 57 appellations now exist, thereby attesting the limits of the model. Furthermore, each AOC is also fragmented: the Médoc has Médoc and Haut Médoc appellations, which, in turn, come under the names of their districts (Margaux, Moulis, Listrac, Saint-Julien, Pauillac, and Saint- Estèphe). Next come the first "crus classés"; all these demarcations which fit together and regulate, a priori, the quality of the wines are, nevertheless, a source of confusion. They make the quality of wines incomprehensible for consumers, who are not connoisseurs, but who are the principle potential consumers.

\footnotetext{
${ }^{18}$ 'Vins de pays' guarantee a geographical origin, which is not the case with table wines (basic vines), but they cannot be approved by the AOC.

${ }^{19}$ Source: http://agreste.agriculture.gouv.fr.
} 


\subsubsection{Châteaux and Brand Proliferation Versus Basic Bordeaux}

During the fifties, more or less only "crus classés" could be found under the name of château, representing a small number, as other vine-growers were developing and selling their wine in bulk to merchants who, in turn, developed brand wines. Over the following decades, the number of small estate wines labelled "château" has multiplied in Bordeaux, to such an extent that, nowadays, only a few wines fail to have this designation. This proliferation, along with mass marketing wines to supermarkets, has contributed to a complex situation where any legibility concerning distinctive signs of quality has been diminished, at the same time undermining the offer.

In the same way, wine brands have also developed. It is well-known that, traditionally, Bordeaux vineyards had very few world-famous brands, excepting Rothschild's MoutonCadet which was launched in 1931. Brands are developing rapidly, particularly in connection with the wine trader's attempts to win back its lost influence. Consequently, modernizing the wine trade has led to a movement of concentration which works in favour of brand development on a global scale. The top-ten Bordeaux brands are (see Table 1), in descending order of sales: Mouton-Cadet (Baronnie), Malesan (Castel), Baron de Lestac (Castel), Cellier Yvecourt (Yvon Mau), Ginestet (Ginestet), Dourthe $\mathrm{n}^{\circ} 1$ (CVBG), Marquis de Chasse (Ginestet), Premius Exigence (Yvon Mau), Calvet Réserve (BVC) and Sirius (Sichel).

As a matter of fact, Bordeaux looks like a two-tier economy [38]. While land prices for appellations such as Saint-Émilion, Margaux, Pomerol and Graves have risen up to millions / ha, there has been, since 2000, a profound depreciation for less prestigious appellations, particularly for basic Bordeaux red. Concerning the entire home market, sales of low-priced Bordeaux wines have continued to drop. This is characteristic of a structural crisis and is attested in figures showing the development of sales volumes in 2007 (cf. Table 1). Prestigious appellations are still increasing their sales: Pomerol, Saint-Émilion, Fronsac: $+3 \%$; Médoc, Graves: $+2 \%$; Bordeaux Whites: $+2 \%$; Bordeaux Moelleux (markedly sweet): $+7 \%$; Bordeaux Liquoreux (luxurious dessert): $+2 \%$; whereas figures for less prestigious appellations have fallen: Côtes de Bordeaux: - 4\%; Bordeaux Reds: - 6\%, Bordeaux Supérieur: - 5\%. Moreover, prices of the less prestigious appellations have fallen steeply from highs in 2001 and 2002. The excellent performances of Bordeaux wines on export markets do not include these wine categories as only $10 \%$ of producers actually export their wines and this activity is concentrated on prestigious châteaux, whose prices have soared since 2000. 2007 vintage wines are sold at two or three times the price of those of 2000.

\subsubsection{Blurring the Signals...}

Confusion has been reinforced by the fact that "concerning terminology, attention can but be focused on the frequent proximity of brands with names of known châteaux or an AOC or rural constructions" [7, p. 34]. In return, the large volumes and similar marketing methods of some châteaux make them resemble brands. It should be noted that several of these châteaux guarantee their identity, as much as possible, through brand registration, which is presumably of value for the most prestigious, but which only ensures trivial protection for many of those whose typicity and identity remain uncertain.

The Bordeaux cluster is therefore litteraly held in hostage by the juxtaposition of its signs of quality: châteaux, brands, appellations, "crus classes", etc.

To summarize our developments on the terroir dynamics of the Bordeaux wine cluster, it appears that Bordeaux survives as a collective brand of great value, but its terroir image suffers from the results of far too much opportunist behaviour and of an excessive differentiation, difficult to interpret in terms of quality. Also, "stowaways" in the form of wine producers take advantage from Bordeaux's generic appellation name without developing a product with the quality required and expected by consumers. Hence, highly hindering disillusions at term because the wine's spontaneous perception will have been tainted.

\section{PRESENT CHALLENGES: FROM INNOVATIONS TO NEW REGULATIONS?}

Since 2008/2009, the Bordeaux wines cluster has been encountering difficulties. It should be noted here that the problems affect not only the cluster of Bordeaux, since most countries of the Old World producers are also struck down by the regression of their market share and by difficulties to optimize the differentiation and quality of their products.

The Bordeaux cluster must confront crucial questionning concerning its terroir original strong point, for which solutions are seeked through motivating its capacity for innovation and reforming the representations of quality linked to the terroir.

\subsection{Motivating the Potential for Innovation}

Challenges are such that Bordeaux wine players have taken the step which separates an albeit regulated but still spontaneous organization, from an organized cluster founded on innovation's most systematic research [8]. The creation of this organized cluster already represents, as it stands, an organizational innovation, aiming at both reinforcing cognitive interactions between the players and at surpassing the blocking coming from collective regulations which are often conflictual. The displayed ambition of this cluster named "Bordeaux-Aquitaine Inno'vin",20, the only one in France based on wine, is to reinforce the region's position as world leader in wine trade and production, as well as the field's competitiveness on a national and international scale, thanks to partnerships between companies and research and training.

Admittedly, Bordeaux's place is still the driving centre in the field of wine. But the fact remains that the vineyard is losing, not its glory, legendary as it is, but its energy [24]. This lack of dynamism lies partly in the former CIVB's orientations. The strong CIVB emphasis on market issues has overshadowed the focus on research and innovation. For example, the cluster lacks any grand architectural projects, touristic organization or marketing of wines developed by

\footnotetext{
${ }^{20}$ This cluster covers not only Bordeaux vineyards but all the vine-growing and wine-producing regions of Aquitaine (South-West France).
} 
sustainable processes or by other vine-growing and winemaking clusters [24]. These short-comings have been highlighted for a long time and a recent project has attempted to find a solution by developing the concept of a "cultural wine centre", associated to the desire to create an events complex and a place for meetings and activities in Bordeaux.

Anyhow, Bordeaux assets are still well-known within the field of innovation. Moreover, the Inno'vin's strategy, with which CIVB recently collaborated, is innovation-driven around subjects like the development of oenological research about wine typicity or about wines at low ethanol content, the adaptation of plant material to climatic changes, the search for alternatives to the use of pesticides and the development of platforms for experimentation and technological diffusion. The players' innovation skills are intended also to be reinforced via the growing spread of both technological and organizational innovations, in order to fight against cluster segmentation between the minoritary élite and the rest of the profession.

Bordeaux's decision to support innovative activities is not exceptional as strong wine regions in Italy adopted a similar strategy. Piedmont, for example, "enacted a law designed to promote the emergence of a regional system of research and innovation, and identify the main guidelines and objectives in terms of supporting scientific research" [39, p. 157]. Tuscany which "exploded on the world stage when the Super Tuscans appeared in the late 1980s" [40], seems to re-focus on its historic roots, from brand strategies to traditional winemaking and some appellation regulations. Not all Italian regions are as famous as Piedmont or Tuscany. This is why these other areas are active in the promotion of tourism local systems. On the Spanish side, the famous Rioja ${ }^{21}$ insists in raising collective organizational devices in order to facilitate the involvement of public authorities into the long term wines strategic plan. Like other European regions before them, Rioja insists in promoting its image and the Rioja wine consumption, through the promotion of wine tourism on the one hand, research, innovation and training in the wine sector on the other hand. According to observers, Spain illustrates two contrasting strategies [41]: those of traditional producers who do not adapt their products portfolio fast enough, and those of the private importers "that could appeal to the American market. These importers, led by Wine Spectator and The Wine Advocate, won the attention and the backing of the major wine outlets in America and in so doing succeeded in correcting Spain's somewhat stodgy downmarket image" [41].

Characterized by similar strategies, because deriving from the same records of receipts, but contrasting, however, because drawing differently to these different sources, the recent Bordeaux strategy mix relies more on technological grounds. In Bordeaux cluster, on the one hand, research into oenology is always very dynamic whereas research into wine typicity, still in its infancy, needs to be developed. In fact, despite its success, oenology still has far to go; the scope for wine production is vast. "Through new aquaintances which it

\footnotetext{
${ }^{21}$ Plan Estratégico del Vino de Rioja 2005-2020, http://www.infoaliment. com/notasprensa.
}

produces, and techniques and procedures it proposes, far from competing in the uniformization of wine taste, oenology, on the contrary, must, opposite to a world-wide "fast wine", contribute to diversifying and personnalizing the global offer as much as possible, and particularly the European offer" [42]. Knowing that this research, well represented in Bordeaux, is indicated at product diversification and typicity, it can, no doubt, be predicted that Bordeaux wines-whose typicity is an asset-will resist the tendancy to uniformization, which others have not resisted. In the end, New World wines will also need to diversify. For all that, is there a future for table wines, or at least for 'vins de pays' 22 in Bordeaux, or should they be sacrificed [37]? Solving this problem requires the implementation of concerted strategies, as they alone are capable of counteracting the downward spiral binding prices and quality, and ultimately undermining the foundations of AOC wine production.

\subsection{AOC and Terroir in the Light of Recent Regulations}

We have observed that, in the Bordeaux region, the vinegrowing and wine-producing conflict between crus/terroir and vine variety/brand no longer has much sense, as references to these two dimensions are so inseparably intertwined. Ultimately, all forms of expression concerning vine-growing and wine-producing (brands, vine varieties, estates) maintain a complex relationship with the notion of terroir [7, p. 219], taking into account the fact that terroir can be agronomical or social, that is to say, characterized, beyond any reglamentary or legal aspects, by cultural and aesthetic aspects, including property rights.

The AOC model has now reached the parting of the ways at the same time as, paradoxically, according to Calvet [43], "the wine's geographical origin has acquired such symbolic intensity that even the most standardized wines can but evoke it". In fact, this reference leads, beyond the divergences and potential conflicts of interest between players, for example between traders and vine-growers, to the re-emergence of the focal issue of quality around the issue of sustainability of the AOCs.

In 2002, some French reports [10] analyzed the question and produced the following alternatives. Either the AOC reinforces its reglementation and controls so as to assert its quality credibility or it is abandoned. As there is a cost to quality, the first choice would rule out some AOC vineyards and give access to 'vins de pays' which fulfil AOC conditions, while table wines would remain open to international brand competition. Eventually, even if it means a reduced offer, French vine-growers would, in this case, keep the AOC. Indication of geographical vine origins subsisting, the second choice would result in favouring large wine companies or distribution networks, which would have succeeded in imposing their brands on the markets.

The recent Wine CMO reform (2008-2009), implemented by the EU and applied in France, has been targetted to reduce overproduction, phase out expensive market intervention measures and promote an alternative winegrowing model, mostly based on that of the New World. This reform proposes the following lines: prohibition of new

\footnotetext{
${ }^{22}$ Vins de pays" benefit the geographical origin label.
} 
plantings in place until 2016, while replanting is allowed where producers undertake to grub up equivalent areas planted with vines ${ }^{23}$, allowing European wines for export to use the wine-making practices forbidden by EU legislation, reorganization of the entire field of wine appellations. The later entails the abolition of unions defending each AOC to be replaced by ODGs (Management Organisms) ${ }^{24}$, privatisation of controls and their concentration, reduction in INAO's role as controller ${ }^{25}$. ODG creation formalizes the separation between controlling signs of quality and origin, on the one hand, and their defence as well as their management, on the other hand. This takes the same stand as the desired clarification, because controls will be carried out hereafter by independent organisms. The second mission is within the scope of ODG, with which vine-growers must have membership in order to obtain a label for their products. If there is only one ODG for one appellation, which was not the case so far because several unions could coexist within the same appellation, it is possible to have several appellations within one ODG [44].

These reforms have not escaped questioning as to the future of AOC wines, owing particularly to ambiguities surrounding both control and quality efficicency. Moreover, the foreseeable AOC dilution within the AOP (EU recognized PDO, Protected Designation of Origin) marks a new system which, in any case, requires a complete review of AOC's qualitative conditions and the probable assimilation of 'vins de pays' in the AOP category. In Bordeaux, the ODG construction principle has been largely copied from the AOC principle. However, in some cases, the AOCs reconfiguration results in the awkward coexistence, in the same geographical area, of several products, white or red wines for example, depending formerly on different appellations, now depending on a same management organism (ODG). Hence the lack, albeit necessary, of clarification concerning the terroir concept, which may be threatened by the substitution of a product principle [44], which would confirm fears expressed by players in the field.

Despite its decisional power as this organization combines all the wine professions, the CIVB is threatened by this spatial reorganization while not willing to devolve powers. This portends difficulties of governance. On the one hand, as the CIVB imposed the same rules to all growers regardless of their specificities; as a result, some players are aggrieved by the choices that CIVB has made in past years. On the other hand, the CIVB is seen to be an impeding actor because it has so far played on the maintenance of the segmentation between generic vineyards, district appellations, crus classés and wine traders'brands. In the present context, one can validly raise the question of whether

\footnotetext{
${ }^{23}$ The EU targeted an area of 175,000 ha to be grubbed up over a three year period (2008-2009 to 2010-2011). For 2009, submitted applications nearly raised 160,000 ha, this over-subscription being due to low wine prices and financial difficulties.

${ }^{24}$ In the Bordeaux cluster, the 57 appellation unions have been replaced by 28 ODG (Organismes de Gestion). But the process is still in progress.

${ }^{25}$ INAO (Institut national des appellations d'origine) recently became INOQ (Institut national de l'origine et de la qualité) (http://www.inao.gouv;fr). This change, towards more localised regulations, reflects the replacement of the control of AOCs, formerly preformed by INAO, by the control of entrusted independant bodies along the rules chosen by each AOC.
}

CIVB might offer future perspectives for a renewed definition of terroir. But this is another story...

\section{CONCLUSIVE REMARKS}

During the above sections, the cluster has emerged as a powerful tool for analyzing local food systems. This concept is, in fact, able to transcend considerations of site specificity, 'à la Marshall' to integrate, with the territorial dimension, other dimensions. Thus, it has been shown that this concept is only relevant in its extensive and multidimensional acceptation. First, we have seen how this holistic approach identifies market and non-market interactions between players of the core value chain. It can then capture the critical elements that represent the links between the core actors with peripheral actors, often providers of complementary and / or strategic skills. This allows for not seeking the determinants of the system's dynamics in external factors. Finally, the articulation of the territorial dimensions to others provides access to the historical trajectory of the system, in terms of coevolution. On the one hand, this view escapes all determinism, both in terms of the system's point of departure and its arrival. Moreover, this interpretation opens the question of the cluster's governance, which, notably, enables actors' strategies and their conflicts of interest to be integrated.

The cluster concept has also provided some empirical insights. We have questionned the cliché of the area of Bordeaux wines being the archetypal terroir based cluster, our demonstration relying on a gradual integrative approach: from the central chain to peripheral actors, and then to the construction of terroir. We have also shown that if Bordeaux is now undoubtedly a cluster, it should be accepted that it has always been due to its origins, particularly through its early internationalization. Furthermore, coevolution dynamics have shown that strong players have changed over the Bordeaux trajectory, and that they are still in an evolving process.

Beyond the Bordeaux example, and drawing also reflection from other authors [26, 36, 45], it is also possible to illustrate that there cannot be any "pure" local or internationalized cluster. Thus, it appears that the wine clusters' development has followed different paths. We have seen that the Bordeaux cluster, classified as an Old World wine producer, integrated the international dimension to its construction. On the contrary, within New World wine producers, if the South Australia cluster has been constituted and built around "the desire to export" [45], "findings from the Waipara cluster (New Zealand) demonstrate that the desire to internationalise played no part in the wine cluster formation" [45, p. 2182]. Reciprocally, whereas the cluster concept is applicable to agrofood areas, research can attest that the social, symbolic and cultural characteristics must be taken into consideration when studying industrial clusters.

Finally, the analysis concerning clusters opens up arguments of strategic decision. In some respect, if terroir appears to be an "invention", it seems to be a very powerful one; but it has been constructed collectively by actors who have to be very careful regarding its meanings and, more important, its credibility. This informal asset has to be valued and thereby encounters critical tests that must be overcome. These tests are currently summarized under what 
Patchell [33] called "the balance, seeming contradictory, for territorial reputation and differentiation". He shows that empowered places, such as St Emilion or Blaye, within the Bordeaux area, are able to find a solution and propose their own model of localized development. Notwithstanding, we would like to point out that, within the Bordeaux cluster as a whole, the AOCs' autonomy is currently limited, despite the window of opportunity opened by the new wine regulations.

Consequently, dominant actors insist on the following "solutions": in the context of a whole Bordeaux market power estimated at about 6 million hl, the cluster can't get away from reducing production by one million hl, which would eventually mean the exit of small estates. These quantitative responses deliberately ignore the necessary consultations in the development of a credible joint development project. These responses must be put into perspective with the governance cluster's weaknesses. Referring again to Mytelka and Farinelli [8], one should observe that "the organized dimension of the cluster is missing in Bordeaux". Indeed, CIVB is the omnipresent actor, but its role is strongly disputed. It is suspected of serving the interests of the wealthiest, i.e. the traders and crus classés. As a matter of fact, this governance has, up to now, maintained terroir antagonisms, between, for example, generics and AOCs, themselves segmented, or wineries versus excellence châteaux. CIVB has also, to a large extent, impeded the project's diversification, with, for example, the weak development of organic wines. As a result, the Bordeaux wines cluster seems to be trapped in quite an entangled situation and one wonders whether the new Wine CMO will or will not help to overcome these governance impediments.

\section{REFERENCES}

[1] Porter ME. Clusters and the new economics of competition. Harv Bus Rev 1998; 76(6): 77-90.

[2] Aylward D. Innovation and inertia, the emerging, dislocation of imperatives within the Australian wine industry. Int J Technol Globalisation 2007; 3(2/3): 246-62.

[3] Porter ME. Location, competition, and economic development: local clusters in a global economy. Econ Devel Quart 2000; 14(1): 15-34.

[4] Marshall A. Principles of economics. London: MacMilllan 1920.

[5] Boschma R. Proximity and Innovation: a critical assessment. Regional Studies 2005; 39(1): 41-5.

[6] Anderson K. The world's wine markets. Globalization at work. London: Edward Elgar Publishing 2004; p. 352.

[7] Réjalot M. Les logiques du château, Filière et modèle vitivinicole à Bordeaux, 1980-2003. Presses Universitaires de Bordeaux 2007: p. 345.

[8] Mytelka L, Farinelli F. Local clusters, innovation systems and sustained competitiveness. Discussion paper series 5. the United Nations University. Institute of New Technologies. Maastricht: The Netherlands 2000; p. 37.

[9] Pitte JR. Bordeaux Bourgogne: les passions rivales. Pluriel: Hachette 2005.

[10] Pomel B. Réussir l'avenir de la viticulture française, plan national de restructuration de la filière vitivinicole française. Paris: Ministère de l'Agriculture et de la Pêche 2006; p. 40.

[11] Bélis-Bergouignan MC, Corade N. La fusion : un moyen de se défaire de la contrainte territoriale. L'exemple des coopératives vitivinicoles aquitaines. Revue d'Economie Régionale et Urbaine 2008; $\mathrm{n}^{\circ} 1$ : 43-68.

[12] Bélis-Bergouignan MC, Corade N, Pesme JO. Strategic operations and concentration in the Bordeaux-Aquitaine region. International Journal of Wine Business Research 2010; Issue 22 (3), special issue.
[13] Bélis-Bergouignan MC, Saint-Ges V. Ways of reducing pesticides use in Bordeaux vineyards. J Cleaner Prod 2009; 17: 1644-53.

[14] Martin R, Sunley P. Deconstructing clusters: chaotic concept or policy panacea? J Econ Geogr 2003, 3: 5-35.

[15] Mc Cormick D. African enterprise clusters and industrialisation: theory and reality. World Devel 1999; 27(9): 1531-51.

[16] Breschi S, Malerba F. The geography of innovation and economic clustering: some introductionary notes. Industrial and Corporate Change 2001; 10(4): 817-33.

[17] Maskell P, Malmberg A. Localised learning and industrial competitiveness. Cambridge J Econ 1999; 23(2), 167-86.

[18] Zimmermann JB. Entreprises et territoires: entre nomadisme et ancrage territorial. Revue de 1'IRES 2005; $n^{\circ} 47: 1$ : 21-36.

[19] Hendrickson MK, Heffernan WD. Opening spaces through relocalization: locating potential resistance in the weaknesses of the global food system. Sociologia Ruralis 2002; 42(4): 348-65.

[20] Markusen A. Sticky places in slippery space: a typology of industrial districts. Econ Geogr 1996; 72: 293-313.

[21] Rychen F, Zimmermann JB. Industrial clusters and the knowledge based economy: from open to distributed structures? Document de Travail n²007-07, GREQAM, Available from: http://halshs.archi ves-ouvertes.fr

[22] Aylward D. Wine clusters equal export success. The Australian and New Zealand Grapegrower and Winemaker 2004; August. Available from: www.grapeandwine.com.au/2004/august/13.html

[23] Ewert J. How competitive is South Africa? Advances and challenges in the transformation of the Cape wine industry. Les Cahiers d'Outre-Mer 2005; 231-232 (Juillet-Octobre), Vignobles de l'hémisphère sud.

[24] Schirmer R. Châteaux bordelais et viña chilienne: la convergence des modèles. Espace et culture (EC) CNRS: UMR8064, Université de la Sorbonne (Paris 4), 2008. Available from: http://halshs. archives-ouvertes.fr

[25] Christensen CM, Verlinden M, Westerman G. Disruption, disintegration and the dissipation of differentiability. Industrial and Corporate Change 2002; 11(5): 955-93.

[26] Overton J, Heitger J. Maps, markets and Merlot: the making of an antipodean wine appellation. J Rural Stud 2008; 24: 440-9.

[27] Williamson OE. The economics of organization: the transaction cost approach. Am J Sociol 1981; 87(3): 548-75.

[28] Giuliani E, Martin Bell M. When micro shapes the meso: learning networks in a Chilean wine cluster. SPRU Electronic Working Papers 2004; No. 115. Available from: http://www.sussex.ac.uk/ spru

[29] Giuliani E. The selective nature of knowledge networks in clusters; evidence from the wine industry. J Econ Geogr 2007; 7: 139-68.

[30] Giuliani E. What drives innovative output in emerging clusters? Evidence from the wine industry. SPRU Electronic Working Papers 2008; $\mathrm{n}^{\circ} 169$. Available from: http://www.sussex.ac.uk/spru.

[31] Malmberg A, Maskell P. Localized Learning Revisited. DRUID Working Paper 2005, N05-19. Available from: http://www.druid. dk/index.php/

[32] Lagendijk A. 'Global lifeworlds' versus 'local systemworlds': how flying winemakers produce global wines in interconnected locals. Tijdschrift voor Economische en Sociale Geografie 2004; 95(5): 511-26.

[33] Patchell J. Collectivity and differentiation: a tale of two wine territories. Environ Planning 2008; A 40(10): 2364-83.

[34] Chauvin PM. Le critique et sa griffe. Ce que fait Robert Parker (aux vins de Bordeaux). ENS Cachan, Terrains \& Travaux 2005/2; $\mathrm{n}^{\circ}$ 9: 90-108. Available from: http://www.cairn.info/article.php/

[35] Stanziani A. La construction de la qualité du vin, 1880-1914. Stanziani A (Ed). La qualité des produits en France (XVIIIe-XXe siècles). Paris: Belin 2003: pp. 123-50.

[36] Garcia-Parpet MF. Le marché de l'excellence: le classement des grands crus à l'épreuve de la mondialisation. Genèses 2004; 56: 7296.

[37] Garcia-Parpet MF. Le terroir, le cépage et la marque: stratégies de valorisation des vins dans un contexte de mondialisation. Cahiers d'Economie et Sociologie Rurales 2001; n 60-61: 149-80.

[38] Anson J. The two speed economy of Bordeaux. Wine Business International 2008, March $22^{\text {nd }}$. Available from: (www.winebusiness-international.com/wbi_108_s50-53_ra_bordeaux.pdf)

[39] Morrison A, Rabellotti R. The role of research in wine: the emergence of a regional research area in an Italian wine production system. Int J Technology and Globalization 2007; 3(2/3): 155-78. 
[40] Shah M. Doing the Italian Job. Wine Business International 2007, February $8^{\text {th }}$. Available from: www.wine-business-international. com/mwbi_408s51-53_ra-tuscany.pdf

[41] Serna (de la) V. Spanish eyes seeing red. Wine Business International, 2007, June $12^{\text {th }}$. Available from: www.wine-bus iness-international.com/wbi_307_s44-49_ra_spain.pdf

[42] Dubourdieu D. La valorisation du terroir par l'oenologie. 6th International Terroir Congress 2006. Bordeaux, France. July 2-7. Available from: www.geologi.it/Campania/download/Gaia_e_Bacco/ Dubourdieu.pdf
[43] Calvet J. Les clusters vitivinicoles français à AOC. Une analyse en termes de biens clubs. Revue d'Economie Régionale et Urbaine 2005; $\mathrm{n}^{\circ} 4:$ : 481-506.

[44] Hinnewinkel J-C, Boivin N. Entre public et privé, la difficile gouvernance des vignobles du nord de l'Aquitaine, Janvier 2010, $\mathrm{N}^{\circ}$ spécial: Privé et public ou l'enchevêtrement des pouvoirs dans le vignoble. Available from: http://revuesshs.u-bourgogne.fr/territo ires duvin/document.php

[45] Dana LP, Kate E, Winstone KE. Wine cluster formation in New Zealand: operation, evolution and impact. Int J Food Sci Technol 2008; 43(12): 2177-90.

Received: February 11, 2010

(c) Marie-Claude Bélis-Bergouignan; Licensee Bentham Open.

This is an open access article licensed under the terms of the Creative Commons Attribution Non-Commercial License (http://creativecommons.org/licenses/by$\mathrm{nc} / 3.0 /$ ) which permits unrestricted, non-commercial use, distribution and reproduction in any medium, provided the work is properly cited. 